\title{
CONGENITAL ABNORMALITIES IN THE AFRICAN NEWBORN
}

\author{
BY \\ MICHAEL SIMPKISS* and ANNE LOWE \\ From Mulago Hospital, Kampala, Uganda
}

(RECEIVED FOR PUBLICATION JANUARY 20, 1961)

As no figures were available on the incidence and type of congenital abnormalities in African peoples, 2,068 consecutive newborn babies were examined by us and the results are given in this paper. They were born between December 1956 and September 1957, in the maternity wards at Mulago Hospital, Kampala, in Uganda. This town has about 40,000 inhabitants. It is on the north shore of Lake Victoria, practically on the Equator and is 4,000 feet above sea level. Mulago Hospital is for Africans only and is the teaching hospital for medical students from the University College of East Africa (Makerere College).

Women are admitted for both normal and abnormal delivery. There is no domiciliary service, but two mission hospitals in the area also have maternity beds. The patients are drawn from many tribes, the Baganda forming the largest group. Antenatal clinics are held, but many of those who attend wait at home to see if natural delivery is possible. It is usual for women to wait until labour starts before coming to hospital. As there are few roads and travel during darkness is difficult, many patients are admitted in false labour. Patients live at varying distances from Kampala and five miles is thought to be near. A few patients are admitted from up-country centres. There are about 3,000 deliveries a year. It is from these patients that our material is taken.

Of the 2,068 babies, 141 were stillborn. It was not possible to do autopsies. It was difficult to see all the stillborn babies because relatives took the body away very soon after delivery. Of these stillborns, 40 were not seen by us, but it is reasonable to expect that any gross abnormality such as anencephaly would have been recorded in the notes. Major abnormalities are always recorded by the midwife or medical student delivering the mother. Two hydrocephalics (one with talipes) and one

* Present address: The Hospital for Sick Children, Great Ormond Street, London W.C.1. macerated foetus with syndactyly, brachydactyly and a funnel deformity of the chest were stillborn.

There were 52 twin births and two of triplets; all these babies were stillborn.

Table 1 shows the abnormalities found. The rate in this series is $5 \cdot 4 \%$. As Neel (1958) points out, any comparison of the frequency of congenital malformations in different series is handicapped by the fact that no two series are made up in the

TABLE 1

CONGENITAL ABNORMALITIES IN 2,068 AFRICAN NEWBORNS

\begin{tabular}{|c|c|c|c|c|c|}
\hline \multicolumn{5}{|c|}{ Malformations } & Number \\
\hline 1. & $\begin{array}{c}\text { Single } \\
A .\end{array}$ & 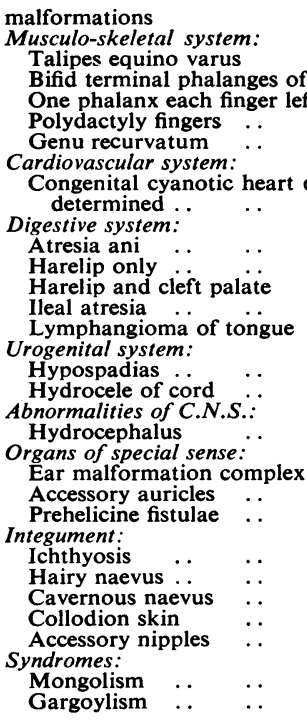 & $\begin{array}{l}\text { f thumb } \\
\text { ft hand } \\
\ldots \\
\ldots \\
\text { disease } \\
\ldots \\
\ldots \\
\ldots \\
\ldots \\
\cdots \\
\ldots \\
\cdots \\
\ldots \\
\ldots \\
\ldots \\
\ldots \\
\cdots \\
\ldots \\
\ldots \\
\end{array}$ & 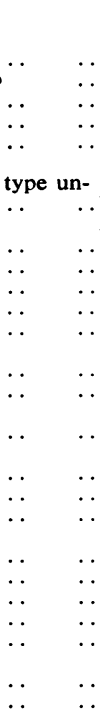 & $\begin{array}{r}1 \\
1 \\
2 \\
1 \\
1 \\
1 \\
3 \\
1 \\
2 \\
2 \\
5 \\
46 \\
1 \\
1 \\
1 \\
1 \\
3 \\
1 \\
1 \\
1\end{array}$ \\
\hline 2. & Multip & $\begin{array}{l}\text { malformations } \\
\text { dactyly and funnel chest } \\
\text { Hydrocephalus and talipes }\end{array}$ & $\begin{array}{l}\text { dactyly, } \\
\text { equino }\end{array}$ & $\begin{array}{l}\text { brachy- } \\
\text { varus } \ldots\end{array}$ & $\begin{array}{l}2 \\
1\end{array}$ \\
\hline & & Total & $\ldots$ & $\cdots$ & 112 \\
\hline
\end{tabular}


TABLE 2

EFFECT OF MATERNAL AGE ON MALFORMATIONS

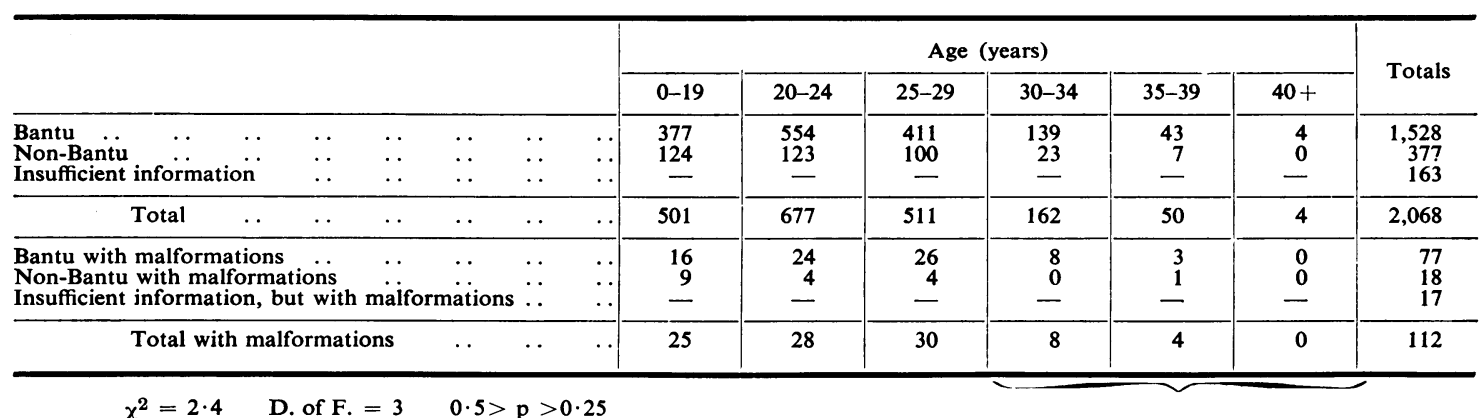

TABLE 3

EFFECT OF BIRTH ORDER ON MALFORMATIONS

\begin{tabular}{|c|c|c|c|c|c|c|c|c|c|c|c|c|c|c|c|c|}
\hline & & & & & & 1 & 2 & 3 & 4 & 5 & 6 & 7 & 8 & 9 & 10 & Totals \\
\hline $\begin{array}{l}\text { Bantu } \\
\text { Non-Bantu } \quad .\end{array} \quad \ldots$ & $\begin{array}{l}\cdots \\
\cdots \\
\cdots\end{array}$ & $\begin{array}{l}\cdots \\
\cdots \\
\cdots\end{array}$ & $\begin{array}{l}\cdots \\
\cdots \\
\cdots\end{array}$ & $\begin{array}{l}\cdots \\
\cdots \\
\cdots\end{array}$ & \begin{tabular}{l|}
$\cdots$ \\
$\cdots$ \\
$\cdots$
\end{tabular} & $\begin{array}{r}559 \\
166 \\
-\end{array}$ & $\begin{array}{r}424 \\
92 \\
\end{array}$ & $\begin{array}{r}257 \\
54 \\
\end{array}$ & $\begin{array}{r}139 \\
33 \\
-\end{array}$ & $\begin{array}{l}70 \\
16 \\
-\end{array}$ & $\begin{array}{l}36 \\
11 \\
-\end{array}$ & $\begin{array}{r}30 \\
3 \\
-\end{array}$ & $\begin{array}{r}6 \\
2 \\
-\end{array}$ & $\begin{array}{r}3 \\
\mathbf{0} \\
-\end{array}$ & $\begin{array}{r}4 \\
0 \\
\end{array}$ & $\begin{array}{r}1,528 \\
377 \\
163\end{array}$ \\
\hline Total & $\cdots$ & $\cdots$ & . & $\cdots$ & $\cdots$ & 725 & 516 & 311 & 172 & 86 & 47 & 33 & 8 & 3 & 4 & 2,068 \\
\hline \multicolumn{2}{|c|}{$\begin{array}{l}\text { Bantu with malformations } \\
\text { Non-Bantu with malformations } \\
\text { Insufficient information, but with }\end{array}$} & $\begin{array}{l}\ddot{m} \\
\text { malfo }\end{array}$ & $\begin{array}{l}\cdots \\
\text { rmation }\end{array}$ & $\cdots$ & $\begin{array}{l}\cdots \\
\cdots \\
\cdots\end{array}$ & $\begin{array}{l}31 \\
12 \\
\end{array}$ & $\begin{array}{r}25 \\
4 \\
-\end{array}$ & $\begin{array}{r}18 \\
3 \\
-\end{array}$ & $\begin{array}{r}7 \\
1 \\
-\end{array}$ & $\begin{array}{r}3 \\
1 \\
\end{array}$ & $\begin{array}{r}2 \\
1 \\
-\end{array}$ & & & & & $\begin{array}{r}86 \\
22 \\
4\end{array}$ \\
\hline \multicolumn{3}{|c|}{ Total with malformation } & . & . & $\cdots$ & 43 & 29 & 21 & 8 & 4 & 3 & & & & & 112 \\
\hline
\end{tabular}

$\chi^{2}=2.32 \quad$ D. of F. $=4 \quad 0.75>p>0.5$

same way. In some series many minor abnormalities are included and in others these are excluded. For example, McIntosh, Merritt, Richards, Samuels and Bellows (1954; booked hospital cases) find an incidence of $7 \cdot 8 \%$ White and $6.3 \%$ non-White infants and they include many minor abnormalities. Other incidences which exclude many minor abnormalities are $1.47 \%$ (Carter, 1950; England, booked cases only), $1.63 \%$ (Coffey and Jessop, 1955; Ireland, hospital cases), 0.67\% (Hegnauer, 1951; Germany, hospital cases), $1 \cdot 11 \%$ (Nowak, 1950; Germany, hospital cases), and $1 \cdot 02 \%$ (Neel, 1958; Japan, general population).

It is better to compare the incidence of particular abnormalities, but in a small series such as this comparison with other large series is not possible. Nevertheless, the incidence of many abnormalities is similar to that seen in Europe, harelip and cleft palate being an example. There are, however, some striking differences between the incidence of some malformations in Africans and in other parts of the world. For example, there were no babies with spina bifida or anencephaly and, moreover, analysis of the hospital records of 5,498 babies born between 1953 and 1955 showed only two cases of anencephaly and two of spina bifida. This low incidence of anencephaly has been noted before among native Africans in Johannesburg and Pretoria by Kahn (1956). In Britain, from three to 12 anencephalics and from three to eight cases of spina bifida would have been seen in 2,000 newborns. Geographical variation in the incidence of anencephaly is discussed in detail by Penrose (1957). He points out that though there is a great variation of frequency of occurrence in different parts of Europe, the incidence is, on the whole, greater among Europeans than among Asians or Africans.

Polydactyly is very common, the incidence being $1.4 \%$. The extra digit is attached in all cases to the proximal phalanx of the little finger, commonly

TABLE 4

MEAN BIRTH ORDER BY MATERNAL AGE AND MALFORMATION

\begin{tabular}{|c|c|c|}
\hline & $\stackrel{\text { Mean }}{\text { Birth Order }}$ & $\begin{array}{c}\text { Mean Maternal } \\
\text { Age in Years }\end{array}$ \\
\hline $\begin{array}{l}\text { All babies } \ldots \\
\text { Those with malformations } \\
\text { Those with prehelicine fistulae } \\
\text { Those with extra digits } \\
\text { Those with malformations other } \\
\text { than prehelicine fistulae or extra } \\
\text { digits } \ldots\end{array}$ & $\begin{array}{l}2 \cdot 34 \\
2 \cdot 17 \\
2 \cdot 33 \\
2 \cdot 00 \\
2 \cdot 09\end{array}$ & $\begin{array}{l}24 \cdot 2 \\
24 \cdot 63 \\
24 \cdot 87 \\
23 \cdot 63\end{array}$ \\
\hline
\end{tabular}


TABLE 5

DISTRIBUTION OF MALFORMATIONS AMONG BANTU AND NON-BANTU

(Malformation rates/1,000 births in brackets)

\begin{tabular}{|c|c|c|c|c|c|c|c|}
\hline & & & & $\begin{array}{l}\text { All Ethnic } \\
\text { Groups }\end{array}$ & Bantu & Non-Bantu & $\begin{array}{l}\text { Insufficient } \\
\text { Information }\end{array}$ \\
\hline $\begin{array}{l}\text { Number of babies examined } \\
\text { All malformations } \ldots \\
\text { Prehelicine fistulae } \quad \ldots \\
\text { Extra digits . } \\
\begin{array}{l}\text { Malformations other than } \\
\text { digits } \quad .\end{array} \quad . .\end{array}$ & 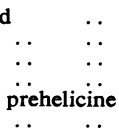 & $\begin{array}{c}\ldots \\
\ldots \\
\ldots \\
\text { fistula } \\
\ldots\end{array}$ & \begin{tabular}{cr|}
$\ldots$ & $\ldots$ \\
$\ldots$ & $\cdots$ \\
$\cdots$ & $\cdots$ \\
and extra \\
$\ldots$ & $\cdots$
\end{tabular} & $\begin{array}{l}2,068 \\
112(54 \cdot 2) \\
46(22 \cdot 2) \\
27(13 \cdot 1) \\
39(18 \cdot 9)\end{array}$ & $\begin{array}{l}1,528 \\
87(56 \cdot 9) \\
40(26 \cdot 2) \\
18(11 \cdot 8) \\
29(19)\end{array}$ & $\begin{array}{r}377 \\
25(66 \cdot 3) \\
6(15 \cdot 9) \\
9(23 \cdot 9) \\
10(26 \cdot 5)\end{array}$ & $\frac{163}{-}$ \\
\hline
\end{tabular}

by skin alone. It is rudimentary, usually made up of one phalanx and sometimes has a nail. In 11 cases the abnormality was unilateral and in 16 bilateral. Two other babies had a similar condition of the toes and one of these had an accessory digit on the little finger of the same side. Both Bantu and non-Bantu were affected, the incidence being insignificantly higher in the non-Bantu. Accessory digits are uncommon in the United Kingdom. Marshall (1959) examined 1,000 consecutive European babies born at Queen Charlotte's Hospital on this point. None had accessory digits.

Prehelicine fistulae were more common, the incidence being $2 \cdot 2 \%$. With this condition the incidence is higher in the Bantu, but the difference is not significant $\left(\chi^{2}=2.9 ; \mathrm{D}\right.$. of $\mathrm{F}$. $\left.=1\right)$. Of Marshall's 1,000 cases referred to above, only two had prehelicine fistulae $(0 \cdot 2 \%)$.

Detailed information on the effect of maternal age and birth order is given in Tables 2,3 and 4. No significant effect is seen. Table 5 shows the distribution of malformations among Bantu and non-Bantu.

\section{Discussion}

As Neel (1958) and others have noted, the total incidence of congenital malformations is comparable in different races. There are, however, striking differences in the incidences of particular malformations. This first series of newborn babies from Africa confirms these observations. Although it was not possible to assess the degree to which our findings were influenced by the admission of obstetric emergencies the total incidence of congenital abnormalities is similar to that of other races. There are significantly fewer severe abnormalities of the central nervous system such as spina bifida and anencephaly. The two cases of hydrocephalus seen were not associated with spina bifida of which there were no examples. There were many more examples of polydactyly and prehelicine fistulae than are seen elsewhere. At first sight it may appear that there is a smaller incidence of congenital heart disease. The figures for this are not accurate, however, since the babies usually stayed in hospital for one to three days only and a follow-up examination was not practicable.

\section{Summary}

The first series describing congenital abnormalities in African newborn babies is presented.

The total incidence of malformed children is $5.4 \%$; this is similar to the rate for other races. There are, however, striking differences in the incidence of particular malformations.

Very few severe abnormalities of the central nervous system such as anencephaly, spina bifida and hydrocephalus are encountered.

There are many more examples of polydactyly and prehelicine fistulae than are seen elsewhere.

Thanks are due to Professor Coralie Rendle-Short of the Department of Obstetrics and Gynaecology at Makerere College, Kampala, for allowing us access to her patients and for her encouragement, and to the Chief Medical Officer, Uganda, for permission to publish. We also gratefully acknowledge much valuable help and criticism from Dr. Cedric Carter of the Medical Research Council's Genetics Unit at The Hospital for Sick Children, Great Ormond Street, London.

\section{REFERENCES}

Carter, C. O. (1950). Maternal states in relation to congenital malformations. J. Obstet. Gynaec. Brit. Emp., 57, 897.

Coffey, V. P. and Jessop, W. J. E. (1955). Congenital abnormalities. Irish J. med. Sci., 30.

Hegnauer, H. (1951). Missbildungshäufigkeit und Gebäralter. Geburtsh. u. Frauenheilk., 11, 777.

Kahn, E. (1956). Personal communication, quoted by Penrose (1957).

Marshall, W. C. (1959). Personal communication.

McIntosh, R, Merritt, K. K., Richards, M. R., Samuels, M. H. and Bellows, M. T. (1954). The incidence of congenital malformations: a study of 5,964 pregnancies. Pediatrics, 14, 505 .

Neel, J. V. (1958). A study of major congenital defects in Japanese infants. Amer. J. hum. Genet., 10, 398.

Nowak, J. (1950). Häufigkeit der Missgeburten in den Nachkriegsjahren, 1945-49. Zbl. Gynäk., 72, 1313.

Penrose, L. S. (1957). Genetics of anencephaly. J. ment. Defic. Res., 1,1 . 